\title{
EFFECT OF KILLING METHODS AND PRESERVATIVE SOLUTIONS ON THE LARVAL BODY LENGTH OF CHRYSOMYA MARGINALIS (DIPTERA: CALLIPHORIDAE)
}

\author{
By
}

\author{
FATMA K. ADHAM ${ }^{1 *}$, SALWA S. RASHED ${ }^{2}$, ZEINAB M. EL-BASHEIR ${ }^{2}$ \\ AND EMAN E. ZAHER ${ }^{2}$
}

Department of Entomology ${ }^{1}$, Faculty of Science, Cairo University, and Department of Zoology, Entomology Section ${ }^{2}$, Faculty of Science, Zagazig University, Zagazig,

Egypt ( ${ }^{*}$ Correspondence: adhamfk@gmail.com)

\begin{abstract}
Estimation of the minimum post mortem interval (PMI) is the essential role of forensic entomology. The accurate determination of this interval depends on the correct larval identification and accurate estimation of larval age. One method of larval age estimation is the larval length measurement. Killing methods and the type of preservative solutions can greatly affect the larval length and therefore reduce the accuracy of PMI estimation. This study was conducted to determine which killing method and preservative can preserve the best larval length of Chrysomya marginalis.

Third instar C. marginalis larvae were either placed live in the preservatives, $10 \%$ formalin, $70 \%$ ethanol, XAA, Kahle's solution and Pample's fluid, or killed by boiling water (BWK) before being placed in the same preservatives. The larval length was recorded after day 1, 3, 5, 7 and 15 and for BWK larvae only; the length was recorded immediately after killing the larvae and before being placed in the preservatives.

The larval length of $C$. marginalis was significantly affected by killing method (live or BWK) and the type of the preservative used. The mean length of the larvae placed live in the preservatives decreases significantly than those killed by boiling water before being placed in the preservatives.It was observed that killing larvae by boiling water then preserved in $10 \%$ formalin and Kahle's solution is the best method for preserving the larval length, but $10 \%$ formalin is not recommended if DNA recovery is desired.
\end{abstract}

Keywords: Blowflies, Forensic entomology, C. marginalis, Larval length, Killing and preservation methods, PMI.

\section{Introduction}

The estimation of the time since death which is known as post mortem interval is the major aim of forensic entomology. In criminal investigation, it was found that the estimation of PMI by entomologists could be more accurate than autopsy (Kashyap and Pillay, 1989). PMI can be estimated based on the age of the oldest larvae collected from the corpse. Erzinclioglu (1986) assured that at a crime scene, the samples collected by entomologists can give more accurate information than those collected by nonentomologists. The initial methods of collection and preservation of larvae can lead to errors in PMI estimation (O'Flynn, 1983; Greenberg and Kunich, 2002). Different methods of killing and preserving larvae had been reviewed. Lord and Rodriguez (1989) Anderson (1995) Benecke (1998) Benecke and Lessig, 2001; Sukontason et al, 2001) used ethanol as a preservative but they used different concentrations. Despite the hot water has been recommended as a killing agent, it is not always used (Hall et al, 1986; Anderson, 1995; Wells and LaMotte, 1995). Wells and Kurahashi (1994) used boiled $70 \%$ ethanol in the killing process of the larvae and used the same solution for preservation. Rodriguez and Bass (1983) preserved the collected insects without killing in a solution containing $10 \mathrm{ml} 40 \%$ formalin, $85 \mathrm{ml}$ of $90 \%$ ethanol, and $5 \mathrm{ml}$ glycerin. Wells and LaMotte (1995) used Kahle's solution for preserving larvae $(30 \mathrm{ml}$ $95 \%$ ethanol, $12 \mathrm{ml}$ formalhyde, $4 \mathrm{ml}$ glacial acetic acid and $60 \mathrm{ml}$ water). Adams and Hall (2003) used boiling water for killing blowfly larvae and $80 \%$ ethanol for presservation. Day and Wallman (2008) compared 
the effect of $100 \%$ ethanol, $10 \%$ formalin and Kahle's solution on Calliphora augur and Lucilia sericata larvae (Diptera: Calliphoridae). They concluded that both Kahle's solution and $10 \%$ formalin were the best preservatives for the larval length, but they excluded $10 \%$ formalin if DNA was wanted to be recovered.

Accordingly, this study aimed to evaluate influence of killing methods and different preservatives on length of Chrysomya marginalis larvae.

\section{Materials and methods}

Colony of $C$. marginalis was established from flies initially collected during June \& July 2017 from El-Mansuryia, Giza Governorate and Dayrout, Egypt. Adults were kept in rearing cages $(35 \times 35 \times 35 \mathrm{~cm})$ under laboratory conditions where the mean ambient temperature of $28 \pm 2^{\circ} \mathrm{C}$ and relative humidity 50-60\%. Adults were supplied with sugar and water and offered fresh beef meat as a protein source and egg deposition medium. Each deposited egg batch was transferred to a plastic jar $(10.5 \times 7 \mathrm{~cm})$ contained fresh beef meat. Newly hatching larvae were transferred to new jar containing fresh meat, covered with muslin and fastened with rubber band. Small number of larvae was kept in

Table 1: Chemical composition of the tested preservatives.

\begin{tabular}{|l|l|}
\hline Preservative & \multicolumn{1}{|c|}{ Chemical composition } \\
\hline XAA & 4 part xylene: 6 parts isopropanol: 5 parts glacial acetic acid \\
\hline Kahle's & 12 parts formaldhyde: 4 parts glacial acetic acid: 60 parts water: 30 part 95\% ethanol \\
\hline Pample's & 6 parts 34\% formalin: 2 part glacial acetic acid: 30 parts water: 15 part 95\% ethanol \\
\hline
\end{tabular}

\section{Results}

The killing method (live or BWK) significantly affected the larval length of $C$. marginalis (Tabs. $2 \& 3$ ). There was a highly significant decrease $(\mathrm{P}<0.001)$ in the mean length of the larvae placed live in the preservatives $(16.58 \pm 0.24 \mathrm{~mm})$ than those killed by boiling water before being placed in the preservatives $(18.61 \pm 0.18 \mathrm{~mm})$. Also, the preservative type and the period had a great effect on the larval body length.

After placing the larvae live in the presservatives and comparing the larval length after day $1,3,5,7 \& 15,10 \%$ formalin revealed a each jar to avoid the intraspecific competetion that might stunt growth, and the effects of maggot-generated heat to stimulate growth (Goodbrod and Goff, 1990). Proper ventilation of jars was considered to prevent death of the larvae.

The post feeding third instar larvae were collected and divided into 2 groups. The first one was placed live in the preservative solutions, while the other group was killed by boiling water before being placed in the preservatives. The preservative solutions were $10 \%$ formalin, $70 \%$ ethanol, XAA solution, Kahle's solution and Pample's fluid (Tab. 1). The larval length for both groups was recorded after 1, 3, 5,7and 15 days and for the $2^{\text {nd }}$ group only, the length was measured immediately after killing and before placing in the preservatives.

The length measurement was taken by using a ruler. Each larva was put parallel to ruler with its anterior end at 0-point of the scale.In general, data obtained during the present study were statistically tested and mean value \pm standard error (Mean \pm SE) was calculated. Computer program SPSS (Statistical Package for Social Sciences) software (Version 14.0 for windows, SPSS Inc.) was used for this purpose.

non-significant difference in larval length $(\mathrm{P}$ $>0.05)$. But, $70 \%$ ethanol showed a nonsignificant decrease from day 1 (16.26 \pm $0.23)$ to day $3(15.78 \pm 0.25)$ which still will be constant during the next tested days $(\mathrm{P}>$ 0.05). A significant decrease from the day 1 $(18.37 \pm 0.19 \mathrm{~mm})$ till day $3(17.67 \pm 0.19 \mathrm{~mm})$, $(\mathrm{P}<0.05)$, and a highly significant decrease after day $5,7 \& 15(16.90 \pm 0.17 \mathrm{~mm})(\mathrm{P}<$ $0.001)$ was recorded when larvae were preserved live in XAA solution.

Kahle's solution showed a non-significant increase from day $1(16.05 \pm 0.25 \mathrm{~mm}$.) to day $3,5 \& 7(16.40 \pm 0.21,16.52 \pm 0.20 \& 16.53 \pm$ 
$0.20 \mathrm{~mm}$, respectively) $(\mathrm{P}>0.05)$ and then a highly significant increase $(17.01 \pm 0.19 \mathrm{~mm})$ after day $15 \quad(\mathrm{P}<0.001)$, Pample's fluid caused a highly significant increased from day 1 to last preservation days $(\mathrm{P}<0.001)$.

After killing larvae in boiling water and placing them in preservatives, both $10 \%$ formalin \& Kahle's solution showed a nonsignificant difference between length measured immediately after BWK (17.66 \pm 0.14 $\& 17.80 \pm 0.17 \mathrm{~mm}$, respectively) and day 1,3 , $5,7 \& 15(17.66 \pm 0.14,17.66 \pm 0.14,17.56 \pm$ $0.13,17.56 \pm 0.13 \& 17.56 \pm 0.13 \mathrm{~mm}$, respectively for formalin10\%) and (18.00 \pm 0.18 mm. for Kahle's) $(\mathrm{P}>0.05)$.
When $70 \%$ ethanol was used, the mean length recorded immediately after BWK $(17.35 \pm 0.22 \mathrm{~mm})$ was highly significantly small than those recorded for the next days: day $1(19.30 \pm 0.23 \mathrm{~mm})$, and constant during next days in this preservative $(\mathrm{P}<0.001)$.

Application of XAA solution and Pample's fluid showed a significant increase $(\mathrm{P}<$ $0.001 \& \mathrm{P}<0.05)$ in larval length. The length measured immediately after BWK was very significantly smaller $(18.05 \pm 0.13 \&$ $17.72 \pm 0.15 \mathrm{~mm}$, respectively) than on subsequent days $(19.05 \pm 0.12 \& 18.26 \pm 0.13 \mathrm{~mm}$, respectively).

Table 2: Effect of different preservatives when larvae of Ch. Marginalis placed live in preservative.

\begin{tabular}{|c|c|c|c|c|c|}
\hline \multirow{2}{*}{ Preservative } & \multicolumn{5}{|c|}{ Mean of larval length (mm) / Day } \\
\cline { 2 - 6 } & 1 & 3 & 5 & 7 & 15 \\
\cline { 2 - 6 } & Mean \pm SE & Mean \pm SE & Mean \pm SE & Mean \pm SE & Mean \pm SE \\
\hline $10 \%$ Formalin & $15.80 \pm 0.77$ & $15.80 \pm 0.77$ & $15.80 \pm 0.77$ & $15.80 \pm 0.77$ & $15.80 \pm 0.77$ \\
\hline $70 \%$ Ethanol & $16.26 \pm 0.23$ & $15.78 \pm 0.25$ & $15.78 \pm 0.25$ & $15.78 \pm 0.25$ & $15.78 \pm 0.25$ \\
\hline XAA & $18.37 \pm 0.19$ & $17.67 \pm 0.19$ & $16.90 \pm 0.17$ & $16.90 \pm 0.17$ & $16.90 \pm 0.17$ \\
\hline Kahle's & $16.05 \pm 0.25$ & $16.40 \pm 0.21$ & $16.52 \pm 0.20$ & $16.53 \pm 0.20$ & $17.01 \pm 0.19$ \\
\hline Pample's & $16.05 \pm 0.22$ & $17.00 \pm 0.18$ & $17.00 \pm 0.18$ & $17.00 \pm 0.18$ & $17.53 \pm 0.15$ \\
\hline
\end{tabular}

Table 3: Effect of different preservatives when larvae of Ch. Marginalis killed in water and put in preservative.

\begin{tabular}{|c|c|c|c|c|c|c|}
\hline \multirow{3}{*}{ Preservative } & \multicolumn{7}{|c|}{ Mean of larval length $(\mathrm{mm}) /$ Day } \\
\cline { 2 - 7 } & Immediately after BWK & 1 & 3 & 5 & 7 & 15 \\
\cline { 2 - 7 } & Mean \pm SE & Mean \pm SE & Mean \pm SE & Mean \pm SE & Mean \pm SE & Mean \pm SE \\
\hline 10\% Formalin & $17.66 \pm 0.14$ & $17.66 \pm 0.14$ & $17.66 \pm 0.14$ & $17.56 \pm 0.13$ & $17.56 \pm 0.13$ & $17.56 \pm 0.13$ \\
\hline 70\% Ethanol & $17.35 \pm 0.22$ & $19.30 \pm 0.23$ & $19.30 \pm 0.23$ & $19.30 \pm 0.23$ & $19.30 \pm 0.23$ & $19.30 \pm 0.23$ \\
\hline XAA & $18.05 \pm 0.13$ & $19.05 \pm 0.12$ & $19.05 \pm 0.12$ & $19.05 \pm 0.12$ & $19.05 \pm 0.12$ & $19.05 \pm 0.12$ \\
\hline Kahle's & $17.80 \pm 0.17$ & $18.00 \pm 0.18$ & $18.00 \pm 0.18$ & $18.00 \pm 0.18$ & $18.00 \pm 0.18$ & $18.00 \pm 0.18$ \\
\hline Pample's & $17.72 \pm 0.15$ & $18.26 \pm 0.13$ & $18.26 \pm 0.13$ & $18.6 \pm 0.13$ & $18.26 \pm 0.13$ & $18.26 \pm 0.13$ \\
\hline
\end{tabular}

\section{Discussion}

The larval length of $C h$. marginalis was significantly affected by killing method and the type of the preservative used. The mean length of the larvae placed live in the preservatives decreases significantly than those killed by boiling water before being placed in the preservatives. No significant difference was observed in the larval length when the larvae were placed live in $10 \%$ formalin or killed by boiling water before preserved in $10 \%$ formalin and Kahle's solution. This agreed with Day and Wallman (2008) who applied the same preservatives on the larvae of $C$. augur and $L$. sericata. They concluded that Kahle's solution and formalin $10 \%$ were the best preservatives for the larval length. There was non-significant decrease in larval length put alive in $70 \%$, but a significant increase when they were killed by boiling water before placed in $70 \%$ ethanol, XAA solution and Pample's fluid, revealed a significant decrease in length when the larvae were placed live in this preservative. This some-how agreed with Tantawi and Greenberg (1993) who found that the larvae of different species shrink when placed live in preservatives. Adams and Hall (2003) observed that larvae of $L$. sericata became shorter when placed live in $80 \%$ ethanol, whereas Ch. vomitoria larvae showed expansion when put in same preservative after hot water killing. Amendt et al. (2007) reported shrinkage in larval length when were exposed live to ethanol. Richards et al. (2013) showed that the size of $C$. 
vicina $3^{\text {rd }}$ instar larvae increased during storage. But, some observations do not agree with Tantawi and Greenberg (1993) who found that $C$. vicina larvae length killed by boiling water neither changes in measure nor after five days storage in $70 \%$ ethanol.

Rosilawati et al. (2014) stated that killing larvae in hot water $\left(80^{\circ} \mathrm{C}\right.$ or $\left.90^{\circ} \mathrm{C}\right)$ reduced the length and protected their morphological appearance. Açıkgöz and Açıkgöz (2018) found that killing $L$. sericata larvae by hot water well preserved their length.

\section{Recommendations}

1- Killing Ch. marginalis larvae in boiling water for about 30 seconds before storage in preservative, made the body rigid and fully extended.

2- Using Kahle's solution as preservation was the best for the larval length.

\section{References}

Adams, ZJO, Hall, MJR, 2003: Methods used for killing and preservation of blowfly larvae, and their effect on post-mortem larval length. Forensic Sci. Int. 138:50-61.

Amendt, J, Campobasso, C, Gaudry, E, Reiter, C, Le Blane, $\mathbf{H}$, et al, 2007: Best practice in forensic entomology-standards and guidelines. Int. J. Legal Med. 121:90-104.

Anderson, G, 1995: The use of insects in death investigations: an analysis of forensic entomology cases in British Columbia over a five year period. Can. Soc. Forensic Sci. J. 28:277-92.

Açıköz, HN, Açıgöz, A, 2018: Effect of killing liquids on the larval length of forensically important Lucilia sericata. Adli. Tıp. Bülteni 23: 36-8.

Benecke, M, 1998: Six forensic entomology cases: description and commentary. J. Forensic Sci. 43:797-805.

Benecke, M, Lessig, R, 2001: Child neglect and forensic entomology. Forensic Sci. Int. 120:1559.

Day, DM, Wallman, JF, 2008: Effect of presvative solutions on preservarion of Calliphora augur and Lucilia cuprina (Diptera: Calliphoridae) with implications for post- mortem interval estimates. Forensic Sci. Int. 179:1-10.

Goodbord, JR, Goff, ML, 1990: Effects of larval population density on rates of development and interactions between two species of
Chrysomya (Diptera: Calliphoridae) in laboratory culture. J. Med. Entomol. 27:338-43.

Greenberg, B, Kunich, JC, 2002: Entomology and Law: Flies as Forensic Indicators. Cambridge University Press, Cambridge.

Hall, RD, Anderson, PC, Clark, DP, 1986: A case of human myiasis caused by Phormiaregina (Diptera: Calliphoridae) in Missouri, USA. J. Med. Entomol. 23:578-9.

Kashyap, VK, Pillay, VV, 1989: Efficacy of entomological method in estimation of postmortem interval: A comparative analysis. Forensic Sci. Int. 40: 245-50.

Lord, WD, Rodriguez, WC, 1989: Forensic entomology: the use of insects in the investigation of homicide and untimely death. Prosecutor 22: 41-8.

O'Flynn, MA, 1983: The succession and rate of development of blowflies in carrion in southern Queensland and the application of these data to forensic entomology. J. Aust. Entomol. Soc. 22: 137-48.

Richards, CS, Rowlinson, CC, Hall, MJR, 2013: Effects of storage temperature on the change in size of Calliphora vicina larvae during preservation in $80 \%$ ethanol. Int. J. Leg. Med. 127: 231-241.

Rodriguez, WC, Bass, WM, 1983: Insect activity and its relationship to decay rates of human cadavers in East Tennessee. J. Forensic Sci. 28: 423-32.

Rosilawati, R, Baharudin, O, Syamsa, R, Lee, H, Nazni, W, 2014: Effects of preservatives and killing methods on morphological features of a forensic fly Chrysomya megacephala (Fabricius, 1794) larva. Trop. Biomed. 31:785-91.

Sukontason, K, Sukontason, K, Vichairat, K, Piangjai, S, Lerttham-nongtham, S, et al, 2001: The first documented forensic entomology case in Thailand. J. Med. Entomol. 38:746-8.

Tantawi, TI, Greenberg, B, 1993: The effects of killing and preservation solutions on estimates of larval age in forensic cases. J. Forensic Sci. 38:702-7.

Wells, JD, Kurahashi, H, 1994: Chrysomya megacephala (Fabricius) (Diptera: Calliphoridae) development: rate, variation and the implication for forensic entomology. Japan. J. Sanit. Zool. 45:303-9.

Wells, JD, LaMotte, LR, 1995: Estimating maggot age from weight using inverse prediction. J. forensic Sci. 40:585-90. 